\section{Yield of Two Hydroponically Grown Tomato Cultivars as Affected by Transplanting Stage or Direct Seeding}

\author{
Martin Makgose Maboko ${ }^{1}$ and Christian Phillipus Du Plooy \\ Agricultural Research Council_Vegetable and Ornamental Plant Research \\ Institute, Private Bag X293, Pretoria, 0001, South Africa
}

Additional index words. direct seeding, early yield, seedlings, Solanum lycorpersicum, transplant stage

\begin{abstract}
Direct seeding or transplanting younger seedlings should reduce costs in hydroponic systems. A 2-year study (2011-12 and 2012-13) was conducted to determine yield of two hydroponically grown tomato cultivars using transplanted seedlings at different growth stages vs. direct seeding. An open bag, using 10-L plastic bags filled with sawdust, was used for direct seeding and transplanting of seedlings at two-, four- or sixleaf stages. Data were collected on early marketable, early total, total, total marketable and cull yield as well as plant fresh and dry mass. In 2011-12, there was increased early marketable and total yields from direct-seeded plants or plants transplanted at the twoor four-leaf stage. Cultivar FA593 produced a higher early marketable yield and total yield compared with 'Linares'. In 2012-13, the highest early marketable and total yields were for plants developed from those transplanted at the two-leaf stage or from those developed from direct seeding. There was no difference between cultivars on marketable and total yield. Cultivar Linares produced the highest plant fresh and dry mass. Early yield can be induced by direct seeding or transplanting seedlings at the two-true leaf stage with no significant effect on total yield and marketable yield. Direct-seeded plants, or transplanting seedlings at the two-leaf stage, will benefit growers by producing tomatoes earlier for the market while eliminating or reducing transplant shock.
\end{abstract}

Direct seeding of hydroponically grown tomatoes (Solanum lycorpersicum) is not a common practice in South Africa, and most growers use transplants. Seedlings for hydroponic production of fresh market tomatoes are commonly transplanted at 6 to 7 weeks after sowing or at the six-leaf stage (Niederwieser, 2001). Some advantages of transplants, compared with direct seeding, include more efficient use of costly hybrid seed, avoidance of unfavorable cool soils, increased crop uniformity, and early harvest (Liptay et al., 1982; NeSmith, 1997, 1999; Orzolek, 1996).

Effects of transplant age on growth and development have been reported for several vegetable species under soil cultivation. Kratky et al. (1982) reported similar yield for Chinese cabbage (Brassica rapa L. ssp. pekinenis) plants developed from transplants of 3 to 6 weeks old. Tomato transplants of among 4, 5, or 6 weeks old did not exhibit significant differences in growth (Leskovar and Cantliffe, 1991). Hall (1989) reported that transplants produced higher late and total yields than direct-seeded plants for

Received for publication 6 Dec. 2013. Accepted for publication 4 Feb. 2014.

We express their gratitude to the Agricultural Research Council for financial support of the study and to Ms. Liesl Morey, Biometry Unit, ARC-CO, for statistical analysis.

${ }^{1}$ To whom reprint requests should be addressed; e-mailmmaboko@arc.agric.za.
A temperature-controlled plastic tunnel was used equipped with a pad and fan $(2 \times 1.1$ $\mathrm{kW}$ fans, $1300 \mathrm{~mm}$ in diameter) cooling system. Ambient temperature in the tunnel during 2011-12 and 2012-13 ranged from 13 to $35^{\circ} \mathrm{C}$ and 11.6 to $36^{\circ} \mathrm{C}$, respectively. Two indeterminate fresh-market tomato cultivars, FA593 and Linares, were either directly sown in 10-L plastic bags or transplanted as seedlings at two-, four-, and six-leaf stages (21, 35 , and 46 d old, respectively). Sawdust was used as the growing medium. A randomized complete block design with four replicates was used. Tomato seed was sown in 200cavity polystyrene trays filled with the commercial growing medium Hygromix $^{\circledR}$ (Hygrotech Pty. Limited, Pretoria, South Africa) and covered with a thin layer of vermiculite after sowing. Each cavity had a volume of $24 \mathrm{~mL}$. With direct seeding, the same volume of growing medium used in seedling trays $(24 \mathrm{~mL})$ was placed in $10-\mathrm{L}$ bags filled with sawdust by making a cavity in the sawdust. Seeds were planted in the seedling medium and also covered with a thin layer of vermiculite. Seeds that were directly sown were irrigated twice a day using drip irrigation with a discharge rate of $70 \mathrm{~mL}$ for 2 min daily. All seedlings were fertigated with Multifeed ${ }^{\circledR}$ (Plaaskem Pty. Limited, Johannesburg, South Africa) at a rate of 1 $\mathrm{g} \cdot \mathrm{L}^{-1}$ of water once daily from the two-leaf stage until the six-leaf stage.

Trials were conducted in tunnels $(10 \mathrm{~m}$ width $\times 30$ m length) covered with a $200-\mu \mathrm{m}$ light diffusive plastic (Evadek green tint; Chris Hefer Construction, Johannesburg, South Africa). The floor of the tunnel was covered with $200-\mu \mathrm{m}$ white plastic. Plants were established at a density of 2.5 plants $/ \mathrm{m}^{2}$ with 10 plants used to collect data in each replication.

Plants were irrigated using one dripper per plant (discharge rate of $35 \mathrm{~mL} \cdot \mathrm{min}^{-1}$ ) at 2 -h intervals seven times daily. The irrigation volume was gradually increased as plants enlarged to ensure that $10 \%$ to $15 \%$ of the applied water leached out of the bags to reduce salt buildup in the growing medium. The composition and chemical concentration of locally recommended fertilizers used were: Hygroponic ${ }^{\circledR}$ (Hygrotech Pty. Limited, Pretoria, South Africa) comprised of nitrogen $(\mathrm{N})\left(68 \mathrm{mg} \cdot \mathrm{kg}^{-1}\right)$, phosphorus $\left(42 \mathrm{mg} \cdot \mathrm{kg}^{-1}\right)$, potassium $(\mathrm{K})\left(208 \mathrm{mg} \cdot \mathrm{kg}^{-1}\right)$, magnesium (30 $\left.\mathrm{mg} \cdot \mathrm{kg}^{-1}\right)$, sulfur $\left(64 \mathrm{mg} \cdot \mathrm{kg}^{-1}\right)$, iron $\left(1.254 \mathrm{mg} \cdot \mathrm{kg}^{-1}\right)$, copper $\left(0.022 \mathrm{mg} \cdot \mathrm{kg}^{-1}\right)$, zinc $\left(0.149 \mathrm{mg} \cdot \mathrm{kg}^{-1}\right)$, manganese $(0.299$ $\left.\mathrm{mg} \cdot \mathrm{kg}^{-1}\right)$, boron $\left(0.373 \mathrm{mg} \cdot \mathrm{kg}^{-1}\right)$, and molybdenum $\left(0.037 \mathrm{mg} \cdot \mathrm{kg}^{-1}\right)$; calcium nitrate $\left[\mathrm{Ca}\left(\mathrm{NO}_{3}\right)_{2}\right]$ comprised of $\mathrm{N}\left(117 \mathrm{mg} \cdot \mathrm{kg}^{-1}\right)$ and calcium (166 mg. $\left.\mathrm{kg}^{-1}\right)$; and potassium nitrate $\left(\mathrm{KNO}_{3}\right)$ comprised of $\mathrm{K}\left(38.6 \mathrm{mg} \cdot \mathrm{kg}^{-1}\right)$ and $\mathrm{N}\left(13.8 \mathrm{mg} \cdot \mathrm{kg}^{-1}\right)$. When all seedlings were 6 weeks old (including direct-seeded seedlings), the irrigation water was supplemented with $800 \mathrm{~g}$ Hygroponic and $600 \mathrm{~g}$ $\mathrm{Ca}\left(\mathrm{NO}_{3}\right)_{2}$ per $1000 \mathrm{~L}$ water until the first flower truss appeared. During development of the first to third flower trusses, fertilizer application was adjusted to $900 \mathrm{~g}$ Hygroponic 
and $700 \mathrm{~g} \mathrm{Ca}\left(\mathrm{NO}_{3}\right)_{2}$ and from the third flower truss to the end of the experiment to $1000 \mathrm{~g}$ Hygroponic, $900 \mathrm{~g} \mathrm{Ca}\left(\mathrm{NO}_{3}\right)_{2}$, and $200 \mathrm{~g}$ $\mathrm{KNO}_{3}$ per $1000 \mathrm{~L}$ of water.

Plants were trellised to a single stem by twisting trellis twine around the main stem and fixing it to a stay wire $2 \mathrm{~m}$ aboveground to support the plant. Side shoots or suckers were removed weekly to maintain a single stem system. When plants had reached the horizontal wire at $2 \mathrm{~m}$, the growing point was removed.

Fruit were harvested weekly at the breaker stage in midsummer from January to February (2011-12 experiment) and December to February (2012-13 experiment). Yield data were collected from 10 plants for each treatment and replicate. The performance of treatments was evaluated using total yield, marketable, and cull yield. Fruit were regarded as cull when they exhibited cracking, zippering, rotting, blossom-end rot, rain control, cat face, or when extra small (less than $40 \mathrm{~mm}$ fruit diameter) (Maboko et al., 2011). Early marketable and total early yields were recorded from the first four harvests, i.e., $84,91,98$, and $105 \mathrm{~d}$ after transplanting. At the end of the experiment, the aboveground plant fresh and dry mass were determined by cutting the plant at the growing medium level. Plants stems and leaves were dried in an oven at $70{ }^{\circ} \mathrm{C}$ for $48 \mathrm{~h}$ for dry mass determination.
Data were subjected to analysis of variance using GenStat ${ }^{\circledR}$, Version 11.1 (Payne et al., 2008). Means were separated using Fisher's protected $t$ test least significant difference (Snedecor and Cochran, 1980).

\section{Results}

The cultivar and transplant stage interaction was not significant for growth and yield. Only the main factors, cultivar and transplant stage, are presented in this experiment. The 2011-12 experiment was ended early (126 d after transplanting) as a result of a high infestation of tomato rust mite (Aculops lycopersici).

Effect of cultivar. In 2011-12, cultivar FA593 produced significantly higher early and total yield as well as cull yield compared with cultivar Linares (Table 1). Total marketable yield and number of marketable fruit were not significantly affected by cultivar (Table 1). However, cultivar FA593 produced a higher early yield than 'Linares'. In 2012-13, cultivar did not affect yield. 'Linares' produced significantly higher plant fresh and dry mass than cultivar FA593 (Table 2).

Effect of transplant stage. In 2011-12, directly sown seeds and seedlings transplanted at the two- or four-leaf stages produced significantly higher early marketable and total yields than seedling transplanted at the six-leaf stage (Table 1). Total yield and total marketable yield for direct-seeded and transplanted tomato were similar (Table 1). In 2012-13, sowing seed directly into the sawdust or transplanting seedlings at the twoleaf stage produced plants that had the highest early number of marketable fruit and early total and marketable yield (Table 2). Total yield or total marketable yield was unaffected by transplant stage or direct seeding (Table 2).

\section{Discussion}

Differences in yield among the cultivars are in agreement with a previous study (Maboko et al., 2012) in that cultivars performed differently in terms of yield and quality. The higher plant fresh and dry mass on cultivar Linares (Table 2) is in agreement with Luitel et al. (2012) who reported that tomato cultivars varied in terms of vegetative growth.

Transplanting seedlings at the two-leaf stage or by direct seeding in sawdust may reduce costs in hydroponic production systems. Furthermore, early harvests from directly seeding or transplanting at the two-leaf stage should provide an advantage of supplying tomatoes early to the market. These results differ from Leskovar and Cantliffe (1991), who found that early total and total fruit yields of tomatoes were similar for 2-, 3-, 4-, or 5-week-old transplants when grown in soil. Leskovar and Cantliffe (1993) reported

Table 1. Effect of transplanting stage on yield of two tomato cultivars (2011-12). ${ }^{\mathrm{z}}$

\begin{tabular}{|c|c|c|c|c|c|c|c|}
\hline Treatment & $\begin{array}{c}\text { Early marketable } \\
\text { yield (g/plant) }\end{array}$ & $\begin{array}{c}\text { Early total } \\
\text { yield (g/plant) }\end{array}$ & $\begin{array}{c}\text { Early number } \\
\text { of marketable } \\
\text { fruits/plant }\end{array}$ & $\begin{array}{l}\text { Total marketable } \\
\text { yield (g/plant) }\end{array}$ & $\begin{array}{l}\text { Total yield } \\
\text { (g/plant) }\end{array}$ & $\begin{array}{l}\text { Number of } \\
\text { marketable } \\
\text { (fruit/plant) }\end{array}$ & $\begin{array}{l}\text { Cull yield } \\
\text { (g/plant) }\end{array}$ \\
\hline \multicolumn{8}{|c|}{ Cultivar } \\
\hline FA593 & $1904 \mathrm{a}$ & $2223 \mathrm{a}$ & $16.00 \mathrm{a}$ & 3388 & $4384 \mathrm{a}$ & 29.28 & $995 \mathrm{a}$ \\
\hline LSD 0.05 & 230.3 & 217.8 & 1.70 & NS & 411.9 & NS & 190.7 \\
\hline \multicolumn{8}{|c|}{ Transplant stage } \\
\hline 6 leaves & $1309 \mathrm{~b}$ & $1592 \mathrm{~b}$ & $11.33 \mathrm{c}$ & 3049 & 3868 & 27.80 & 819 \\
\hline Direct seeding & $1810 \mathrm{a}$ & $2083 \mathrm{a}$ & $15.34 \mathrm{ab}$ & 3258 & 3929 & 28.69 & 671 \\
\hline LSD 0.05 & 325.7 & 308.0 & 2.41 & NS & NS & NS & NS \\
\hline
\end{tabular}

${ }^{\mathrm{z}}$ Values in a column followed by the same letter are not significantly different $P \leq 0.05$, Fisher's protected $t$ test.

NS $=$ nonsignificant; LSD $=$ least significant difference.

Table 2. Effect of transplanting stage on yield of two tomato cultivars (2012-13). ${ }^{2}$

\begin{tabular}{|c|c|c|c|c|c|c|c|c|c|c|c|}
\hline Treatment & $\begin{array}{c}\text { Early } \\
\text { marketable } \\
\text { yield } \\
\text { (g/plant) }\end{array}$ & $\begin{array}{l}\text { Early } \\
\text { total yield } \\
\text { (g/plant) }\end{array}$ & $\begin{array}{l}\text { Early number } \\
\text { of marketable } \\
\text { fruit/plant }\end{array}$ & $\begin{array}{c}\text { Total } \\
\text { marketable } \\
\text { yield } \\
\text { (g/plant) }\end{array}$ & $\begin{array}{l}\text { Total } \\
\text { yield } \\
\text { (g/plant) }\end{array}$ & $\begin{array}{l}\text { Percent } \\
\text { marketable } \\
\text { yield }\end{array}$ & $\begin{array}{l}\text { Number of } \\
\text { marketable } \\
\text { fruit/plant }\end{array}$ & $\begin{array}{l}\text { Cull yield } \\
\text { (g/plant) }\end{array}$ & $\begin{array}{l}\text { Percent } \\
\text { cull } \\
\text { yield }\end{array}$ & $\begin{array}{l}\text { Plant fresh } \\
\text { wt (g/plant) }\end{array}$ & $\begin{array}{c}\text { Plant } \\
\text { dry mass } \\
\text { (g/plant) }\end{array}$ \\
\hline \multicolumn{12}{|c|}{ Cultivar } \\
\hline Linares & 1130 & 1300 & 6.88 & 5889 & 6684 & 87.88 & 37.2 & 795 & 12.12 & $1935 \mathrm{a}$ & $266.5 \mathrm{a}$ \\
\hline LSD 0.05 & NS & NS & NS & NS & NS & NS & NS & NS & NS & 207.3 & 31.12 \\
\hline \multicolumn{12}{|c|}{ Transplant stage } \\
\hline 4 leaves & $886 \mathrm{~b}$ & $1019 \mathrm{~b}$ & $5.17 \mathrm{~b}$ & 5918 & 6731 & 87.68 & 38.7 & 813 & 12.32 & 1880 & 248.0 \\
\hline 6 leaves & $695 \mathrm{~b}$ & $810 \mathrm{~b}$ & $4.51 \mathrm{~b}$ & 5734 & 6394 & 89.26 & 39.5 & 660 & 10.74 & 1786 & 246.2 \\
\hline Direct & $1301 \mathrm{a}$ & $1425 \mathrm{a}$ & $7.91 \mathrm{a}$ & 5888 & 6664 & 88.15 & 40.1 & 776 & 11.85 & 1747 & 232.4 \\
\hline LSD 0.05 & 257.5 & 279.9 & 1.71 & NS & NS & NS & NS & NS & NS & NS & NS \\
\hline
\end{tabular}

${ }^{2}$ Values in a column followed by the same letter are not significantly different, $P \leq 0.05$, Fisher's protected $t$ test.

$\mathrm{NS}=$ nonsignificant; $\mathrm{LSD}=$ least significant difference. 
that bell pepper transplants had significantly higher and earlier yields than direct-seeded peppers when grown in soil. In this study, the delay in harvest for plants developed from transplants of either the four- or six-leaf stage was compensated for by higher yields during the late harvests.

Plants developed from direct seeding or from transplants established at the two-leaf stage might have performed better than plants developed from seedling transplanted at fouror six-leaf stages as a result of unrestricted taproot development and greater root proliferation in the larger sawdust volume in a 10-L planting bag (Leskovar and Stoffella, 1995). The early yield might be the result of early root growth, improved water and nutrient uptake, and less competition for light as might have occurred in higher density seedling trays. Commercial seedling growers produce seedlings in seedling trays with small cavities to reduce the amount of growing medium and produce more seedlings per unit area. This might result in seedlings competing for sunlight as the leaf canopy becomes crowded. Seedlings that were allowed to grow to the six-leaf stage might have increased root restriction as a result of a small cavity size (NeSmith and Duval, 1998). When seed is directly sown or transplanted at a young stage, i.e., two-leaf stage, into 10-L plastic bags, seedling roots are not be restricted (NeSmith and Duval, 1998). Peterson et al. (1991) reported that increased root mass and decreased rooting space lead to competition for available oxygen, further reducing the amount of pore space.
In conclusion, direct-seeded plants, or transplanting seedlings at the two-leaf stage, will benefit growers by producing tomatoes earlier for the market while eliminating or reducing transplant shock. Direct seeding or transplanting seedlings at the two-leaf stage would reduce production costs in hydroponic production systems.

\section{Literature Cited}

Hall, M.R. 1989. Cell size of seedling containers influences early vine growth and yield of transplanted watermelons. HortScience 24:771773.

Kratky, B.A., J.K. Wang, and K. Kubojiri. 1982. Effects of container size, transplant age, and plant spacing on Chinese cabbage. J. Amer. Soc. Hort. Sci. 107:345-347.

Leskovar, D.I. and D.J. Cantliffe. 1991. Growth and yield of tomato plants in response to age of transplants. J. Amer. Soc. Hort. Sci. 116:416420.

Leskovar, D.I. and D.J. Cantliffe. 1993. Comparison of plant establishment method, transplant or direct-seeding, on growth and yield of bell pepper. J. Amer. Soc. Hort. Sci. 118:17-22.

Leskovar, D.I. and D.J. Cantliffe. 1994. Transplant production systems influence growth and yield of fresh-market tomatoes. J. Amer. Soc. Hort. Sci. 119:662-668.

Leskovar, D.I. and P.J. Stoffella. 1995. Vegetable seedling root system: Morphology, development, and importance. HortScience 30:1153-1159.

Liptay, A., E.F. Bolton, and V.A. Dirks. 1982. A comparison of field-seeded and transplanted tomatoes grown on a clay soil. Can. J. Plant Sci. 62:483-487.

Luitel, B.P., P.B. Adhikari, C.S. Yoon, and W.H. Kang. 2012. Yield and fruit quality of tomato
(Lycorpersicon esculentum Mill.) cultivars established at different planting bed size and growing substrates. Hort. Environ. Biotechnol. 53:102-107.

Maboko, M.M., C.P. du Plooy, and I. Bertling. 2011. Comparative performance of tomato cultivars cultivated in two hydroponic production systems. S. Afr. J. Plant Soil 28:97-102.

Maboko, M.M., C.P. du Plooy, and I. Bertling. 2012. Comparison of performance of tomato Cultivars in temperature vs. non-temperature controlled plastic tunnel. Acta Hort. 927:405411.

NeSmith, D.S. 1997. A comparison of yields and yield components from different muskmelon (Cucumis melo L.) production systems. J. Veg. Crop. Prod. 3:37-45.

NeSmith, D.S 1999. Root distribution and yield of direct seeded and transplanted watermelon. J. Amer. Soc. Hort. Sci. 124:458-461.

NeSmith, D.S. and J.R. Duval. 1998. The effect of container size. HortTechnology 8:564-567.

Niederwieser, J.G. 2001. Guide to hydroponic vegetable production. 2nd ed. Agricultural Research Council, Roodeplaat, Vegetable and Ornamental Plant Institute. Pretoria, South Africa.

Orzolek, M.D. 1996. Stand establishment in plasticulture systems. HortTechnology 6:181-185

Payne, R.W., D.A. Murray, S.A. Harding, D.B. Baird, and D.M. Soutar. 2008. GenStat for Windows $^{\circledast}$. 11th ed. Introduction. VSN International, Hemel Hempstead, UK.

Peterson, T.A., M.D. Reinscl, and D.T. Krizek. 1991. Tomato (Lycopersicon esculentum Mill. cv 'Better Bush') plant response to root restriction. Root respiration and ethylene generation. J. Expt. Bot. 42:1241-1249.

Snedecor, G.W. and W.G. Cochran. 1980. Statistical methods. 7th ed. Iowa State University Press, Ames, IA. 